Mągorzata Peroń

Katolicki Uniwersytet Lubelski im. Jana Pawła II

\title{
Nie ma domu. Krajobraz kulturowy w literaturze (wybrane przykłady)
}

Krajobraz może stanowić wspólny obszar zainteresowań geografa i literaturoznawcy (Zawadzka 2014: 11). Jak zauważa Mikołaj Madurowicz, geografia w literaturze nie ogranicza się jedynie do „dyspozycji przestrzennej” postaci, rzeczy tworzących planu przedstawienia (Madurowicz 2012: 362). Literatura w spotkaniu z geografią pełni różnorodne role: formułowanie i rekonstruowanie doświadczenia przestrzennego, wartościowanie rzeczywistości, budowanie narracji egzystencjalnej, stwarzanie świadectwa kulturowego określonej przestrzeni, informowanie, instruowanie, ilustrowanie, ułatwianie zrozumienia określonego zjawiska (Madurowicz 2012: 363). Najważniejszym nurtem we współczesnych badaniach humanistycznych, który analizuje związek pomiędzy przestrzenią a kulturą, jest geopoetyka. Wypracowane przez nią narzędzia badawcze są pomocne w praktyce interpretacyjnej i kierują badania literaturoznawcze w stronę interdyscyplinarności. Jak stwierdza Elżbieta Rybicka:

Kategorie geograficzne lub przestrzenne nie mają charakteru tylko opisowego, ale są pojęciami operacyjnymi, za pomocą których można konceptualizować i uchwycić w nowej prespektywie takie kluczowe dla badań literackich problemy jak literatura, poetyka, podmiotowość, język, czytanie, recepcja, gatunki i obiegi (Rybicka 2014: 9). 
Celem niniejszego artykułu jest prześledzenie na wybranych przykładach z literatury sposobów funkcjonowania krajobrazu jako przestrzeni symbolicznej, bogatej w elementy materialne, które w doświadczeniu percepcji zostają zmetaforyzowane i przeniesione poza obszar ściśle fizykalny. Istotne jest znalezienie odpowiedzi na pytanie, czym charakteryzuje się doświadczanie krajobrazu, jaką rolę odgrywają zmysły w badaniu otoczenia, jaką pozycję zajmuje obserwator, na jakich zasadach i z jakim skutkiem dokonuje subiektywnej interpretacji pejzażu, w jaki sposób przestrzeń jest odbierana, odczuwana i wartościowana przez bohaterów literackich. Są one możliwe do uchwycenia w toku działań o charakterze interdyscyplinarnym. Klasyczne i mające mocne umocowanie w literaturoznawstwie takie kategorie jak przestrzeń, czas, narracja, bohater mogą być wsparte przez narzędzia wypracowane przez geografię kulturową, geografię percepcji, geografię doświadczenia. Osiągnięcia wymienionych nurtów, należących do geografii humanistycznej lub tzw. nowej geografii kulturowej (Dorocki 2008: 283, Tobiasz-Lis 2014: 129), połączone z badaniami literaturoznawców pozwalają na wpisanie krajobrazu do kanonu tekstów symbolicznych. Oznacza to możliwość metaforycznego, nie jedynie fizykalnego odczytywania i wysuwania wniosków znaczących dla współczesnych dyskursów pamięci, tożsamości. Krajobraz jawi się wówczas jako „zbiór miejsc znaczących” (Tuan 1987: 14). Wnioski płynące z subiektywnej i opartej na percepcji zmysłowej lektury widzialnych przestrzeni można uczynić uniwersalnymi i na równi znaczącymi wobec gestów opisywania, interpretowania i rozumienia świata poprzez symbole zawarte w klasycznych wytworach kultury człowieka: literaturze, sztuce, muzyce.

Jako przykłady literackie zostaną omówione wyimki z twórczości Stefana Żeromskiego (Ludzie bezdomni, dzienniki pisarza), poetyckie zapiski Czesława Miłosza (cykl Litwa, po pięćdziesięciu dwóch latach z tomu Na brzegu rzeki) oraz autobiograficzna proza Moniki Sznajderman Pusty las. Różnorodność przywołanych przykładów, wynikająca z odmiennych konwencji literackich oraz kontekstów historycznych i biograficznych, ma na celu nie tylko ujawnienie bogactwa realizacji motywu krajobrazu jako symbolu i metafory, ale również opracowania wspólnych punktów, niezależnych od formy i czasu powstania dzieła.

Kultura jako zjawisko przestrzenne i społeczne stanowi przedmiot badań geografii humanistycznej od ponad stu lat (Dorocki 2008: 283). W jej obrębie na początku xx wieku pojawiła się koncepcja krajobrazu kulturowego, dzięki czemu dotychczasowe rozumienie krajobrazu jako wyłącznie tworu materialnego zostało wzbogacone o elementy niematerialne. W badaniach geografów kultury istotne stało się prześledzenie takich aspektów jak: kategoria wyobrażeń, więzi z miejscem, znaczenie wytworów człowieka, symboliczne ujmowanie 
świata, problem tożsamości kulturowej oraz terytorialnej mieszkańców (Dorocki 2008: 285). Ważny w badaniach nad krajobrazem jest wymiar osobistego doświadczania przestrzeni jako miejsca urodzenia bądź zamieszkania, dzięki którym owa przestrzeń jest odbierana i wartościowana. Ślady takiego przywiązania do określonego terytorium, wynikające z doświadczenia, przechowuje literatura. Prezentuje ona różne postawy wobec krajobrazu, rodzinnego terytorium i otoczenia. Wymienione postawy są obecne w warstwie narracyjnej, fabularnej, językowej i mogą być interpretowane za pomocą narzędzi wypracowanych przez geografię kulturową i zaadaptowanych przez geopoetykę. Jak podkreśla Urszula Myga-Piątek, badanie koncepcji krajobrazu nie jest jedynie domeną geografii, ale także innych dziedzin, wykraczających poza nauki ścisłe (Myga-Piątek 2014: 28). W badaniach krajobrazu i jego związków z kulturą znajdują się takie nurty, w których poza jego materialną formą istotna jest także jego warstwa znaczeń. Jest to wspólny aspekt w poszukiwaniach geografów oraz interpretatorów literatury. Kolejnym punktem, który zbliża geografię do badań literackich, jest „przedmiot badań (miejsce doświadczone przez człowieka krajobraz kulturowy), jak i nowe metody hermeneutyczne (nacisk położony na rozumienie, a nie wyjaśnienie)" (Rybicka 2014: 132).

Florian Plit wyróżnia pięć podejść względem krajobrazu: ujęcie klasyczne, fizycznogeograficzne, realne (materialne), semiotyczne (symboliczne), estetyczne (Myga-Piątek 2014: 31-32). Analizie podlega krajobraz jako swoista forma przechowywania pamięci, wyobrażeń, przeświadczeń, sądów (Jędrzejczyk 2001; Rembowska 2002; Czepczyński 2006; Madurowicz 2012). Krajobraz staje się „tekstem”, „ikoną”, „spektaklem”, „metaforą”, ponieważ przez widzialne elementy materialne można dostrzec ukryte treści niematerialne (Myga-Piątek 2014: 32). Jak podkreśla Myga-Piątek, krajobraz kulturowy składa się z elementów

pochodzenia przyrodniczego i antropogenicznego (kulturowego), które ze sobą oddziałują tworząc system dynamicznych relacji kształtujących tzw. przestrzeń kulturową, dającą się interpretować także od strony niematerialnych wartości (Myga-Piątek 2014: 33).

Przedstawiciele nowej geografii kulturowej (John Brinckerhoff Jackson, Denis Cosgrove, Yi-Fu Tuan) traktują zatem krajobraz tak samo jak literaturoznawcy badający relację pomiędzy bohaterem a przestrzenią i analizujący jego postawy wobec krajobrazu jako tekstu, którego znaczenie należy odczytać.

Krajobraz to kod, w który wpisane jest zmaganie człowieka z naturą (Skrok 2008: 110). Przekłada się to także na stosowane w procesie interpretacji pejzażu słownictwo: krajobraz jest tekstem, metaforą, spektaklem, ikoną do odczytania 
(Myga-Piątek 2014: 32), obserwator zaś jest czytelnikiem. Metafora badacza jako czytelnika przypomina rozumienie krajobrazu zaproponowane przez Stanisława Vincenza. Dla niego krajobraz jest rodzajem „pisma światowego”, które należy odczytać (Królikowski, Rykała 2016: 17), a kluczową rolę odgrywa w tym procesie wzrok (Niewiadomski 2018: 393). Vincenz odwołuje się do zadań, jakie stawia przez malarzem pejzaż, i każdy, kto chce go zamknąć w malarskich kształtach, powinien pamiętać, że najlepiej by było dla widza odczytać więcej z krajobrazu niż z książek (Vincenz 1980: 411-412). Pisarz, opisując sposób interpretacji krajobrazu, jako przykład podaje malowniczy pejzaż rzeki Dunaj, która „[...] jest istotnością widzialną i niewidzialną” (Vincenz 1980: 379), a zadaniem malarza jest odkrywać nie zewnętrzne przedmioty, lecz „istotności i ich tajemnice" (Vincenz 1980: 379). To spojrzenie na krajobraz jako jednocześnie rzeczywistość widzialną i niewidzialną, dosłowną i metaforyczną, materialną i symboliczną, obecną i zanurzoną w przeszłości, lokalną i wspólnotową, stałą i zmienną stoi w centrum zagadnień krajobrazu kulturowego i przenika do literackich realizacji tego zagadnienia.

Przydatne w analizie obecnych w poezji i prozie postaw wobec pejzażu są także ustalenia geografii percepcji, stanowiącej jeden z nurtów geografii behawioralnej i geografii humanistycznej (Tobiasz-Lis 2014: 129). Geografia percepcji bada, w jaki sposób przestrzeń jest odbierana, odczuwana i wartościowa przez ludzi. Joanna Plit podkreśla, że krajobraz kulturowy rozumiany jest poprzez zmysły, całościowo, zatem istotne są tu wszystkie narzędzia sensualnego odczuwania świata (Plit 2011: 16). Warto zatem w praktyce interpretacji tekstu sprawdzić, za pomocą jakich zmysłów dokonuje się percepcja krajobrazu i czy któryś z nich jest szczególnie waloryzowany, a tym samym odwraca tradycyjne myślenie o krajobrazie jako doświadczeniu jedynie wizualnym (Kowalczyk 2008: 128). Maciej Pietrzak przypomina, że w latach osiemdziesiątych xx wieku Tadeusz Bartkowski wprowadził do teorii geografii pojęcie krajobrazu multisensorycznego, inaczej też określanego jako wielobodźcowego, wielozmysłowego (Pietrzak 2008: 104). Krajobraz nie tylko dostarcza bodźców wzrokowych, ale też oddziałuje przez zapach, smak, węch i dotyk. Pietrzak postuluje, by nie badać poszczególnych zmysłów w izolacji, lecz przyjąć strategię synestezji, a zatem odbierania jednego bodźca wieloma zmysłami (Pietrzak 2008: 105). Na gruncie badań literackich istotne są także rozpoznania Paula Rodawaya, który do badań nad rolą doświadczenia i rozumienia otoczenia poprzez zmysły wprowadził pojęcie sensuous geographies. Relacja do miejsc i przestrzeni nie tylko jest wielowymiarowa, wielozmysłowa i emocjonalna, ale także jest podstawą do formułowania wniosków na temat pojmowania krajobrazu przez człowieka i rozumienia sensów przekraczających doświadczenia czysto sensoryczne 
(Rodaway 1994: 16). Beata Frydryczak podkreśla, że dzięki percepcji krajobrazu poprzez zmysły uruchomiony zostaje mechanizm uczestnictwa i zaangażowania w krajobraz, w którym widzialne staje się doświadczanym (Frydryczak 2016: 9). W literaturze istnieje jeszcze jeden czynnik, który wspiera percepcję zmysłową to pamięć. Uruchamiana jest ona przez stratę, wydziedziczenie z krajobrazu, ściślej opuszczenie domu rodzinnego i potrzebę powrotu do niego. Kluczową rolę, podobnie jak w sensuous geographies, odgrywa percepcja indywidualna, przeżycia jednostki i subiektywizm spojrzenia (Rodaway 1994: 22).

W geografii humanistycznej i w sensuous geographies wiodącą rolę w rozumieniu krajobrazu przypisuje się indywidualnemu obserwatorowi, który poddaje się bodźcom płynącym z otoczenia i podejmuje proces ich interpretacji. Celem tej lektury jest uchwycenie sensów symbolicznych, niedosłownych. Włoski teoretyk krajobrazu Almo Farina wyróżnia trzy rodzaje krajobrazu: krajobraz naturalny, obiektywny; krajobraz indywidualny, ponieważ postrzegany jest poprzez zmysły; trzeci zaś to krajobraz obserwatora. Jest to taki rodzaj pejzażu, w którym krajobraz indywidualny zostaje dodatkowo przefiltrowany przez system wartości patrzącego (Farina, Bogaert, Schipani 2005: 319). W literaturze i w sztukach wizualnych znajdujemy odbicia krajobrazu rzeczywistego, co wynika z samej istotowości sztuki związanej z takimi zjawiskami jak mimesis, reprezentacja czy platońska teoria idei (Gołaszewska 1984: 12). W badanych przeze mnie przykładach z literatury (Żeromski, Miłosz, Sznajderman) ujawniają się bohaterowie jako zaangażowani w otoczenie obserwatorzy, którzy uczestniczą w nim poprzez zmysłową percepcję oraz dokonują jego metaforyzacji dzięki wyposażeniu ich przez autorów w system wartości, doświadczeń, przekonań.

Należy podkreślić, że literacki obserwator krajobrazu jest zawsze wędrowcem, pielgrzymem, turystą. Odnotowywanie śladów przeszłości i ich interpretowanie wiąże się z podróżą. Towarzyszy jej jeszcze jedno, poza zmysłami, narzędzie służące rozumieniu zmienności czasu i przestrzeni: wyobraźnia. Jest to narzędzie, którego wystrzegają się tradycyjne dziedziny archeologii. Autor Wielkich Rozdroży. Ćwiczeń terenowych z archeologii wyobraźni pisze:

Obecny świat jest wyłącznie krajobrazem kultury, zapisem tysiącletnich zmagań człowieka z przyrodą, kodem i tekstem możliwym do odczytania. Taką też lekturą będziemy się zajmować, fenomenologią miejsc i form kulturowego krajobrazu, która przy naszym aktywnym działaniu, poprzez obserwację, rzeczową analizę i wyobraźnię, przekształci się w hermeneutykę - metodę odczytywania z drobiazgów, aluzji i powierzchownych wrażeń prawdy bogatszej, niż ukazuje to powierzchowna naoczność i potoczne doświadczenie. Taka jest arche- 
ologia krajobrazu - zaglądanie pod podszewkę świata, ignorowanie jego potocznej oczywistości, dostrzeganie rzeczy ważnych, zajmujących tam, gdzie inni widzą rzeczy banalne lub nie widzą nic zgoła (Skrok 2008: 110).

Monika Sznajderman, autorka opublikowanej w 2019 roku książki Pusty las, mówiąc o procesie jej tworzenia, podkreśla rolę wyobraźni badacza, który próbuje po śladach zapisanych w krajobrazie dotrzeć do historii człowieka:

Same dokumenty nie wystarczą, by zbudować opowieść - potrzebna jest też wyobraźnia. I zrozumienie, że ostatecznie każda historia, którą opowiemy, przefiltrowana przez naszą wiedzę, wyobraźnię i wrażliwość, jest opowieścią także o nas [...]. Czerpię więc $\mathrm{z}$ historii, ale ta historia przekracza własne granice, nie zamyka się w przeszłości i staje się teraźniejszością, staje się naszą własną historią (Nogaś, Grzymisławski 2020: 97).

Postawa wobec krajobrazu łączy się zatem z postacią zaangażowanego (m.in. z powodu przywiązania do rodzinnego miejsca, poczucia powinności wobec nieobecnych) obserwatora, wkraczającego na ścieżki przeszłości i pamięci. Spojrzenie na krajobraz wykracza zatem poza rejestrowanie bodźców wizualnych (Wieczorkiewicz 2008: 103). Pejzaż jawi się w całej swej zmienności, jest efektem nieustannej przemiany fizykalnej, podlega także zmienności historycznej i społecznej (Frydryczak 2013: 49). Podejmowanie prób uchwycenia tych zmian jest domeną nie tylko nauk ścisłych i społecznych, ale także działań literackich i artystycznych, w których krajobraz objawia się jako źródło narracji o minionym.

Robert Traba podkreśla, że krajobraz kulturowy zmusza wędrowca do spojrzenia nie tylko na to, co chciałby zobaczyć, co aktualnie mu odpowiada, ale także na to, co trudne, okryte milczeniem, wyparte (Traba 2009: 103). Tematyka ta jest ściśle związana $\mathrm{z}$ dyskursem na temat pamięci, a odbieranie pejzażu jako nakładających się na siebie warstw minionych zdarzeń staje się argumentem na rzecz wieloznaczności przeszłości i jej odczytań (Traba 2009: 101). W badaniach nad znaczeniem krajobrazu przypisana mu zostaje rola opowieści o poprzednich pokoleniach, co ma swoje odzwierciedlenie $\mathrm{w}$ terminologii odwołującej się do czynności czytania. Krajobraz staje się narracją o doświadczeniu zarówno zbiorowym, jak i jednostkowym. Zachętą do tej swoistej lektury są elementy materialne, będące efektem ingerencji człowieka w naturę (pola, sady, drogi, ścieżki), i miejsca symboliczne, wpisane w krajobraz (cmentarz, dom, osada, obiekty związane z kultem). Każdy z tych elementów zyskuje podwójne zna- 
czenie: związane z przeszłością i teraźniejszością, która może być w pełni zrozumiana dzięki perspektywie spojrzenia wstecz (Ingold 2014: 147).

W literackich odsłonach krajobraz jest zatem swoistym narracyjnym palimpsestem. To przestrzeń, która poprzez formę topograficzną rozsnuwa przed patrzącym opowieść o przeszłości. W pejzaż wpisane są ślady przeszłości, związane $z$ poprzednimi mieszkańcami obserwowanych terenów. Jest to warte podkreślenia: przeszłość przemawia do obserwatora za pomocą śladów związanych z działalnością człowieka. Tym samym zmusza patrzącego do zadania pytania o to, kim on (teraźniejszy) sam jest wobec poprzednich pokoleń. Sznajderman w rozmowie z Michałem Okońskim na temat krajobrazu Beskidu Niskiego, który swoją topografią odzwierciedla historię miejsca, mówiła, że konkretna fizyczność tego miejsca prowokuje umysł do zadawania pytań: „skąd jesteśmy, co tu robimy, jak to jest, że żyjemy i jak mamy żyć po kimś?” (Okoński 2019: 33).

Szczególną odmianę krajobrazu, wpisaną w dyskurs pamięci i historii, stanowią „skażone krajobrazy”. Pojęcie to zostało sformułowane przez Martina Pollacka, który w eseistycznej książce o takim właśnie tytule opisuje miejsca, w których dokonywano aktów ludobójstwa (autor analizuje przypadki z Europy Środkowej i Wschodniej, które miały miejsce w xx wieku). Ofiary zbrodni miały pozostać bezimienne, a fakty o tych dramatycznych wydarzeniach nieujawnione. Pollack przywołuje bowiem takie zbrodnie, których ślady były dokładnie zacierane, bo dokonywano ich w ukryciu, często w tajemnicy (Pollack 2014: 20). Miejsca masowych grobów miały stać się niewidoczne dla osób postronnych, wtopić się w krajobraz i, jak pisze autor, „stać się nim” (Pollack 2014: 20). Zostały one na zawsze naznaczone stygmatem historii (Pollack 2014: 23). Przywracanie pamięci o wydarzeniach odbywa się dzięki przyjęciu postawy słuchacza - narrator szuka świadków wydarzeń lub osób, które słyszały o nich. Sam bowiem krajobraz jest dla niego niemy. W archeologii pamięci odczytanie historii, również tej bolesnej, odbywa się nie tylko poprzez poznawanie słownych czy pisanych relacji o przeszłości, ale także dzięki widocznym śladom w pejzażu. Przekształcenia, które dokonywane były poprzez działania człowieka, są niecałkowicie wchłonięte przez naturę i możliwe do uchwycenia.

Literackie przetworzenia krajobrazu kulturowego związane są z odkrywaniem historii rodzinnych, zarówno jednostkowych, jak i tych związanych z doświadczeniem pokoleń czy grup, również etnicznych. Bardzo istotne w podejściu do przestrzeni znaczącej w literaturze jest funkcjonowanie pamięci. Patrzący zanurza się w przeszłość związaną z osobistym doświadczeniem, często wracając do domu rodzinnego lub miejsca, w którym ten dom kiedyś był. Tropi wówczas ślady widoków zapamiętanych z dzieciństwa i porównuje z tym, co faktycznie jest. Powrót do rodzinnego gniazda ma często charakter konfrontujący z bo- 
lesnymi doświadczeniami i związany jest z niemożnością powrotu. Źródeł tego negatywnego doświadczenia należy szukać w historii (wojny, wysiedlenia, zmiany geopolityczne). Pamięć pozwala, jak pisze Magdalena Bauchrowicz, na zmniejszenie skutków wyroków historii, zwłaszcza utraty tego, co najważniejsze, najbardziej ukochane (Bauchrowicz 2012: 32-33). By przywołać przeszłość, potrzebne są przedmioty, przestrzenie, symbole, które umożliwiają powrót do minionego i odtworzenie miejsc utraconych (Karwińska 2017: 70).

Literackie tematy związane są z odkrywaniem tożsamości i nawiązywaniem symbolicznej łączności z przodkami. Spotkanie z krajobrazem splata w nierozerwalny węzeł doświadczenie indywidualne z wydarzeniami zainicjowanymi poza powracającym (np. utrata domu w skutek wysiedlenia, zniszczenia wojennego). Literatura ukazuje także bohatera, przychodzącego jako obcy i odkrywającego przeszłość terenów, które stają się dopiero jego domem. Jest to szczególnie charakterystyczne dla książek opisujących przemiany zachodzące po II wojnie światowej, zwłaszcza na Kresach i tzw. Ziemiach Odzyskanych (Trzeszczyńska 2013: 107). W tym szczególnym wypadku opowiadający przyjmuje na siebie rolę strażnika pamięci o byłych mieszkańcach. Jego zadaniem jest przypisanie do pochłanianych przez krajobraz śladów materialnych imion właścicieli, zrekonstruowanie ich losów.

Motyw odkrywania przeszłości lub powracania do znajomej przestrzeni poprzez krajobraz obecny jest w literaturze różnych epok. W twórczości pisarzy polskich ze względu na uwarunkowania historyczne, staje się popularny w II połowie XVIII i XIX wieku (Kowalczykowa 1982; Cieński 20oo; Lyszczyna 2010). Rodzimy pejzaż wpisuje się w sposoby myślenia i mówienia o Polsce w czasach zaborów, która musiała szukać różnych dróg podsycania wyobraźni swoich mieszkańców i budowania wspólnoty, również poprzez literaturę i sztukę. Ballady i romanse, Pan Tadeusz Adama Mickiewicza, poezja Teofila Lenartowicza (np. wiersze Moje strony, Jak to na Mazowszu, Mały światek) to jedne z wielu dzieł, w których motyw rodzimego pejzażu staje się nośnikiem treści symbolicznych: wyraża tęsknotę, miłość do ojczyzny, nadzieję na odzyskanie niezależności. Łączy w sobie doświadczenie zarówno indywidualne, jak i zbiorowe.

Literackie spojrzenie na pejzaż i postawy wobec niego ma kilka wymiarów. Po pierwsze, otwiera zagadnienia związane z dziedzictwem, przynależnością terytorialną, ale także społeczną, wyznaniową, etniczną oraz wspólnotą doświadczeń. Po drugie, wiąże się z problematyką utraty, wykorzenienia, u podstaw których leżą różnorodne przyczyny, np. konflikty zbrojne, w tym na tle etnicznym, decyzje polityczne zmieniające granice i skutkujące wysiedleniami, nierówności społeczne prowadzące do utraty domu. Po trzecie, interpretowanie otaczającej przestrzeni wiąże się nie tylko z pragnieniem wzmocnienia poczucia 
przynależności, ale także z dążeniami do odkrywania własnej tożsamości. W postawach bohaterów literackich można zauważyć potrzebę, by stać się kolejnym pokoleniem, które poprzez poznanie przeszłości otrzymuje prawo przynależności do określonego terytorium. Często wspólnota z dawnymi mieszkańcami jest budowana poprzez odnajdywanie materialnych śladów w pejzażu, które następnie uruchamiają proces poznawania historii swojej okolicy.

Pierwszy wymiar: chęć przynależności i powrotu do rodzinnych stron, by to poczucie wzmocnić, zostały zapisane w historii Joasi Podborskiej, bohaterki Ludzi bezdomnych Stefana Żeromskiego. W pamiętniku nauczycielki znajduje się relacja z jej przyjazdu do rodzinnego dworu w Głogach. Rodzina bohaterki po powstaniu styczniowym podzieliła los wielu ziemian i utraciła swój majątek. Przyczyniła się do tego także sytuacja rodzinna, śmierć rodziców, rozproszenie rodzeństwa. Dom przeszedł w ręce nowych właścicieli, a Joasia przez wiele lat nie odwiedzała rodzinnych stron. Podczas swojej podróży guwernantka postanawia odwiedzić dwa ważne dla niej miejsca: mogiłę rodziców na cmentarzu w Krawczyskach oraz swój dawny dom. Wędrówkę rozpoczyna spotkanie z pejzażem. Bohaterka obserwuje krajobraz i w nim szuka materialnych śladów, które pomogą odnaleźć grób rodziców. Teren jest opuszczony, ziemne mogiły wchłonęła bujna przyroda. Joasia przywołuje wspomnienia tego miejsca, przypomina sobie, że jej bliscy zmarli pochowani zostali koło „kępy jasnej brzeziny” (Żeromski 1982: 187) i próbuje ją odszukać. Młodemu zagajnikowi, przywoływanemu przez pamięć, powierzona zostaje funkcja drogowskazu. Odnalezienie konkretnego miejsca nie jest jednak możliwe, ponieważ realny pejzaż zmienił się radykalnie: kępy brzeziny tworzą „całe gąszcze” (Żeromski 1982: 187). Nie jest on tożsamy z tym, który przechowuje pamięć bohaterki. Joasia jednocześnie jest w ważnym dla siebie miejscu, a jednocześnie zmienność natury i upływający czas pozbawiają ją możliwości faktycznego spotkania z tym, co dla jej biografii, także wewnętrznej, jest ważne. Postulat Tuana, że krajobraz wypełniają „miejsca znaczące” (Tuan 1987: 14), okazuje się w tej literackiej kreacji zaprzeczony. Pejzaż poprzez zmysł wzroku, zbliża się raczej do koncepcji terytorium, którą zaproponował Pollack - utraconego, przemilczanego, skażonego, a zatem niewidocznego. Przyczyna zniknięcia miejsca jest jednak inna niż w przypadku terenów, o których w książce Skażone krajobrazy pisał eseista. Cmentarz w Krawczyskach pochłania żywioł przyrody nieokiełznanej przez rodziny czy przyjaciół zmarłych. Ich nieobecność, być może spowodowaną, tak jak w przypadku Joasi, koniecznością opuszczenia domu i podejmowania różnorakich prób przetrwania, wykorzystuje niejako żywioł przyrody. Dla Joasi otaczająca natura zakrywa zatem ślady przeszłości. Przywoływanie znaczeń i wartości takich jak przywiązanie do rodziców odbywa się jedynie w prze- 
strzeni pamięci, ale prawdziwość wyłanianych w niej przedmiotów nie może zostać potwierdzona przez elementy istniejące realnie. Odtworzenie miejsca utraconego nie jest zatem możliwe (Karwińska 2017: 70).

Podczas podróży do rodzinnego dworu bohaterka Żeromskiego lokalizuje znaczące dla siebie miejsca poprzez charakterystyczne ślady, istniejące w krajobrazie. Inaczej niż w przypadku doświadczenia nierozpoznawalnego widoku cmentarnych mogił, tutaj następuje spotkanie zapamiętanego z obecnym, istniejącym. Pejzaż jawi się jako multisensoryczny, odbierany jest nie tylko wizualnie, ale także poprzez dźwięki i zapachy:

Przede mną była grobla prowadząca do dworu. Wszystko inne, inne... Nowe gaje drzew wyrosły. Tylko iskry palące się na falach stawu i na śliskich łodygach sitowia, tylko zapach tataraku i wilgotna woń rokit ta sama. Biało-żółte lilie wodne ze swych szerokich liści uśmiechały się do mnie i sączyły w serce wino radości (Żeromski 1982: 192).

Joasia doświadcza, jak dawniej znajome widoki ulegają przemianie. Obraz zmiennej przyrody, która „wszystko pożera” (Żeromski 1982: 193), staje się metaforą utraty bezpiecznego życia. Pojawiające się w dzienniku nauczycielki ekspresyjne opisy natury współgrają z młodopolską stylistyką pejzażu. Jego przywoływanie pozwala także na stworzenie obrazu emocji bohaterki. Głęboki smutek, rozpacz i tęsknota potęgowane są przez okrutny żywioł natury. Joasia stwierdza: „Grunt obojętny został sam jeden i jak przed wiekami zazielenił się do końca. Nic tu nie ocalało po moim ojcu, po mojej matce, po mnie i po braciach" (Żeromski 1982: 193). Człowiek zostaje wpisany w cykl przyrody i musi poddać się przemijaniu. Tak samo jak zatarły się ślady po mogiłach, tak samo stanie się z rzeczami, które wytwarzają kolejne pokolenia. Żeromski ukazuje dwie strony natury: witalną, piękną, zapisaną we wspomnieniach Joasi i przychodzącą do niej po latach w drobnych błyskach na wodzie, w wyglądzie kwiatów. Są to bezpieczne rejony dawnego świata, znane z imienia gatunki roślin, o których bohaterka mówi „siostrzyczki moje rodzone” (Żeromski 1982: 190). Drugie oblicze ukazuje krajobraz - przestrzeń, którą trudno oswoić, z naturą rozrastającą się poza to, co dotychczas było znajome. Niewielka kępa drzew przy mogile matki po latach okazuje się nieznaną gęstwiną, w której nie można już odnaleźć drogi. Rodzinne strony przekształcają się w grunt pokryty zielenią.

W Ludziach bezdomnych ślady przeszłości zapisane są w krajobrazie, ale są też przez niego nieustannie wchłaniane i znikają przed wędrowcem. Jedyną możliwością, by dotrzeć do przeszłości, jest uruchomienie pamięci. Podróż do minionego czasu odbywa się według pamiątek odciśniętych w krajobrazie. 
Przyrodnicze drogowskazy stanowią niewielkie, drobne roślinki, krzewy, kwiaty łąk i ogrodu. Rozpoznane przez bohaterkę, nie są jednak w stanie przywrócić obecności zmarłych. Tym samym odsłaniają bolesną prawdę o kruchości życia.

Odczucia Joasi zapisane w jej pamiętniku są literacką transpozycją przeżyć Żeromskiego, którego zapamiętany z wczesnych lat dzieciństwa dom i majątek stał się własnością obcych ludzi. Śmierć matki pisarza w 1881 roku, niegospodarność ojca, długi, konflikty rodzinne były przyczyną tego, że kiedy w 1883 roku Antonina Żeromska (macocha) została wdową, nie była w stanie utrzymać majątku. Jak pisze Artur Hutnikiewicz, nie miała ona „żadnych możliwości sprostania twardym warunkom dzierżawczego kontraktu. Masa spadkowa pokryła zaledwie liczne wierzytelności państwowe i prywatne. Ciekoty zostały bezpowrotnie utracone" (Hutnikiewicz 2000: 41). W Dziennikach pod datą 15 kwietnia 1887 roku Żeromski zapisał:

Wczoraj piechotą poszedłem do Wilkowa. Z Góry Wilkowskiej objąłem okiem całą moją dolinę. [...] Z mego białego dworu wił się słupem dym, białe ściany świeciły. [...] Ten dwór był nasz, wydał cię na świat i wydał ze siebie na cmentarz dwoje twoich rodziców. [...] Trzeba zrozumieć tę mowę starego domu, gdy się nie ma domu - i trzeba sobie przebaczyć te łzy gorzkie i tę otchłań tęsknoty za tym, co już nigdy, nigdy, nie wróci... (Żeromski 1954: 200).

Doświadczenie pustki i niemożność powrotu do utraconego domu są udziałem kolejnych pokoleń, których losy splotły się z wydarzeniami dziejowymi. Przyroda jest ostatnim śladem po nieobecnych członkach rodziny, w osobistej topografii odgrywa rolę lokalizującą: potwierdza, że kiedyś tu był dom, tu były mogiły najbliższych. Przez przybysza zanurzającego się w przeszłość jest także odczytywana w sposób symboliczny: zapewnia o prawdziwości wspomnień. W obu przekazach wymieniane są rośliny znane z przydomowych ogrodów, zagajników, sadów. Oswajają przestrzeń rozległego krajobrazu i wskazują na dawną obecność człowieka, są strażnikami pamięci o nieobecnych (Skrok 2008: 155). Zarówno w pamiętniku Joasi Podborskiej, jak i w dzienniku pisarza przywołany zostaje krajobraz prywatny. Jego doświadczenie ma dwa źródła. Pierwszym jest odbieranie miejsca poprzez zmysły, które zgodnie z koncepcją geografii zmysłów Rodawaya ujawniają dodatkowe sensy, wykraczające poza odbiór bodźców. Drugim jest pamięć indywidualna, wobec której przestrzeń pełni aktywną rolę dla praktyk memoratywnych (Rybicka 2014: 307). Zarówno w literackiej kreacji, jak i w dziennikowym świadectwie te dwa źródła prowadzą do konstatacji związanej z niemożnością odzyskania utraconych bliskich 
i szczęśliwego czasu. Możliwe jest jedynie ich przywoływanie w pamięci. Drobne i rozpoznawalne w perspektywie osobistej elementy pejzażu stanowią medium przeszłości i potwierdzają prawdziwość wspomnień.

Zdzisław Skrok, opisując tereny dawnej Łemkowszczyzny, zwraca uwagę na połączenie krajobrazu naturalnego z tym, który był aranżowany przez człowieka. Na styku obu rodzi się przestrzeń pamięci, w której krajobraz oglądany zarówno w mikro-, jak i w makroskali ma znaczenie symboliczne, emocjonalne, historyczne, polityczne (Rybicka 2014: 307). Opuszczone wioski w Beskidzie Niskim stały się dla autora miejscem eksploracji, podczas której rozpoznawał minione i dokonywał swoistych praktyk memoratywnych:

Dla wędrowca, beskidzkiego powsinogi, stanowią [przydomowe sady - M.P.] zagadkę i wyzwanie. Nagle zdumiony przystaje, dziwiąc się i medytując, skąd nagle na ścieżce pojawiły się rozsypane małe, czerwonozłote jabłuszka albo granatowe węgierki [...]. Taka jest leśna archeologia krajobrazu srogo doświadczonego przez historię xx wieku, nie ze śladów ludzkich budowli ukrytych pod leśnym poszyciem odczytująca zapomnianą przeszłość, ale ze zrujnowanych drzewostanów wyprowadzająca swe wnioski (Skrok 2008: 159).

Krajobraz traktowany jest zatem jako drogowskaz pozwalający odbyć wędrówkę po ścieżkach pamięci. W świadectwach mieszkańców wysiedlonych terenów w Beskidzie Niskim powraca wielokrotnie informacja o tym, że jednym punktem odniesienia podczas szukania śladów gospodarstwa były zapamiętane krzewy, drzewa owocowe. Nie przetrwały budynki, ścieżki zarosły, dorodna natura szybko wchłonęła przez lata i z trudem podporządkowywaną przestrzeń (Potaczała 2019: 29, 50, 236, 282).

Trudne doświadczenie utraty domu i powrotu po latach do rodzinnego miejsca cechuje podwójna optyka patrzącego: rozpoznawanie znanych punktów i odkrywanie zachodzących zmian w krajobrazie. W poetyckiej odsłonie tego doświadczenia widoczne jest także poczucie straty i świadomość przemiany krajobrazu, która symbolicznie odnosi się do przemijania człowieka. W poezji, eseistyce, dziennikach Jarosława Iwaszkiewicza i Czesława Miłosza te elementy spotkania z rodzinnym krajobrazem są wyraźne. Przywołani twórcy z indywidualnymi biografiami oraz swoistą poetyką zaznaczyli w swojej pracy pisarskiej wspomnienie domu i krajobrazu prywatnego, oglądanego w mikroskali. Po latach, kiedy nastąpi powrót, to właśnie krajobraz stanie się drogowskazem do przeszłości. Rodzinne okolice zostały bowiem opuszczone na kilkadziesiąt lat, a powroty odbywają się do miejsc, które geograficznie przynależą już do 
innych państw lub w których dokonały się radykalne zmiany nie tylko wizualne, ale i społeczne. Iwaszkiewicz, urodzony w 1894 roku w Kalniku na Ukrainie, w swojej twórczości i wspomnieniach wielokrotnie powracał do kraju urodzenia (Bażan 2011: 167). Poeta odbył także dwie podróże w rodzinne strony $(1958,1974)$. W Książe moich wspomnień Iwaszkiewicz opisuje powrót do miejsca, w którym przyszedł na świat. Było to w jego rodzinnym domu, po którym pozostał tylko ślad: „gęstsza i bardziej zielona trawa określona konturem znikłego domu. Mogłem więc na tym konturze pokazać nawet miejsce, gdzie stało łóżko mojej matki, w którym się urodziłem" (Iwaszkiewicz 2010b: 19). Pisarz spodziewał się, że właściwie nic tam nie znajdzie, a jednak zależało mu na tym, aby uchwycić to, co bezpowrotnie znikło.

Miłosz, urodzony w 1911 roku w Szetejniach, powraca w maju 1992 roku, po pięćdziesięciu dwóch latach nieobecności, w rodzinne strony (Franaszek 2011: 31). W jednym z wywiadów wyznawał:

Jest w tym moim przywiązaniu do Litwy, właściwie do jednego powiatu, coś dziwnego. Są to więzi niemal mistyczne. Piszę o tym w wierszu „Łąka”. Kiedy po 52 latach wróciłem w moje rodzinne strony i zobaczyłem na łące te same kwiaty i trawy, które oglądałem w dzieciństwie, zapłakałem ze szczęścia. To chyba coś znaczy, prawda? (To jest we mnie... 2000: 46).

Podobnie jak w siedzibie Iwaszkiewiczów, nic nie zostało z jego domu: „ nie ma domu, jest park, choć stare drzewa wycięto" (Miłosz 2011: 1060). Poeta odnalazł jedynie krzew dzikiego bzu, rosnący zwykle na obrzeżach ludzkich siedzib i rozrastający się w opuszczonych miejscach, należący do tzw. roślin ruderalnych.

W twórczości poetyckiej Miłosza istotne miejsce zajmują wiersze-wspomnienia o rodzinnej krainie, jej przyrodzie, mieszkańcach (Rudziewicz 2011: 194). Poeta z wielką dbałością odnotowuje szczegóły rodzinnej okolicy, przywołuje nazwy kwiatów, drzew, rzek, zagajników i wiosek. Miłosz „wypracował całą poetykę opartą na toku gawędowych wyliczeń i informacji etnograficznych, różnostek dotyczących «kraju i obyczaju», anegdot, wypisów typu kolbergowskiego, wspominiarskich obrazów, często wielkiej piękności” (Zieniewicz 1987: 20). Przestrzeń geograficzno-historyczna staje się przestrzenią symboliczną, w której nakładają się na siebie czas, miejsca, doświadczenia. Sprzyja temu zastosowana do opisu krajobrazu technika ujęć filmowych. Jak pisze Beata Tarnowska, krajobrazy przenikają się niczym poszczególne klatki filmu: 
[...] znika perspektywa i zza jednego planu prześwieca drugi, obraz staje się płaską jednolitą płaszczyzną, na której powierzchni usytuowane zostają równolegle elementy przedmiotowe. W wyniku nakładania się na siebie dwóch klisz przestrzennych powstaje trzecia, nie istniejąca na planie empirycznej rzeczywistości, mentalna i metaforyczna przestrzeń-hybryda (Tarnowska 1996: 82).

Można powiedzieć, używając tytułu jednego z tomów poety, że ta szczególna kraina, przefiltrowana przez sensualistyczną wyobraźnię i doskonałą pamięć, to „Świat. Poema naiwne”. To w tej krainie bije źródło Doliny Issy, książki stanowiącej swoistą mitologię i apoteozę rodzinnego domu i pejzażu. Maria Berkan stwierdza, że poetyckie obrazy Litwy to także symbol wewnętrznego - nie tylko geograficznego - osiedlenia (Berkan 1998: 84).

Literackim owocem podróży na Litwę w 1992 roku jest cykl wierszy Litwa po pięćdziesięciu dwóch latach z tomu Na brzegu rzeki (1994). Tonację wierszy-wspomień wzbogaca melancholia i postawa rozrachunkowa. Pojawia się porównanie obrazów zapisanych w pamięci z realnymi widokami. Poruszanie się po śladach przeszłości to uważna obserwacja krajobrazu, która łączy się z fascynacją poety drzewami, polnymi kwiatami, chwastami i ziołami (Zajas 2007: 114). Miłosz pisze:

Gdzie były wioski i sady, teraz tylko pola.

Zamiast starodrzewiu - młode lasy

Obniżono poziom wód, znikła mszaryna,

I z nią zapach bahunu, cietrzewie i żmije (Miłosz 2011: 1061).

W przywołanym fragmencie wiersza Pewna okolica powraca prezentowana w wielu innych utworach idea przemijania i przeobrażania się ziemskich, zmysłowych kształtów w nowe formy. Pod wpływem czasu, ale także i historii, zmienia się pejzaż. To, co domowe, bliskie, związane z pracą człowieka, zostaje zagarnięte przez naturę. W wierszu Miłosza strata zostaje zasygnalizowana w bardzo subtelny sposób. Po pierwsze, wskazówki dotyczące czasu ułatwiają konfrontację obecnego z minionym. To drugie wydaje się bogatsze, bardziej wartościowe, pełniejsze. Kiedyś były i wioski, i sady, dzisiaj są jedynie pola. Okazuje się, że czas i historia odejmują coś ze świata, pomniejszają jego różnorodność, a nie tylko wymieniają jego elementy na nowe. Wartościowanie dwóch czasów widoczne jest także w użyciu wyrazów określających las: kiedyś starodrzew, dzisiaj młody las. Ten dawniejszy odnosi się semantycznie zarówno do natury, jak i do historii, może też kojarzyć się z podaniami, baśniami, legendami. Nato- 
miast dzisiejszy „młody las” jest dopiero zapowiedzią przyszłości. Obserwacja krajobrazu związana jest z podwójną optyką spojrzenia: najpierw dostrzegany jest pejzaż, później następuje zbliżenie i zogniskowanie uwagi na szczegółach przyrodniczych. Przywołanie konkretnych nazw roślin, gatunków ptaków i zwierząt łączy się z doświadczeniem pamięci. Wyławia ona nie tylko kształty natury, ale też zapachy. Jan Błoński podkreślał, że poetyka Miłosza zbudowana jest na miłości szczegółu, autor Pieska przydrożnego wielokrotnie odwołuje się do osobistych, jednostkowych doświadczeń (Błoński 1998: 58-59). Ukazywanie świata w skali mikro jest jednym ze sposobów ocalania od niebytu jednostkowej rzeczywistości (Rambowicz 2011: 176). Poeta przypomina przyrodnika cierpliwie zbierającego różne gatunki roślin i tworzącego z nich album-pamiątkę. Ten swoisty zbiór jest nie tylko świadectwem kresowego pochodzenia poety, ale także emblematem refleksji metafizycznej (Rambowicz 2011: 177).

Miłosz spotyka po ponad pięćdziesięciu latach najpierw pejzaż, który jednocześnie jest uchwytny i rozpoznawalny. W cytowanym już wierszu Pewna okolica pisze: „I gąszcz porasta ślady dawnych ścieżek” (Miłosz 2011: 1060). Ubywaniu znajomego świata (zniknął nie tylko dom, budynki gospodarcze, ale również „lipowa aleja”, „szuwary” i „lilie wodne”) towarzyszy świadomość podmiotu, który dostrzega analogie między sobą a krajobrazem. Rodzinny pejzaż jest swoistym alter ego dla bohatera cyklu Litwa po pięćdziesięciu dwóch latach; zmiany, jakie obserwuje w otaczającej przyrodzie, dotyczą także jego. Podróżnik stwierdza: „Równocześnie, rok po roku, traciliśmy liście / Zasypywały nas śniegi, ubywało nas" (Miłosz 2011: 1060). Zanurzenie w krajobraz, odbieranie go zmysłowo przynosi spokój pomimo świadomości przemijania. Wydaje się, że koncepcja pejzażu obecna w poezji Miłosza bliska jest teorii Rodawaya, który w centrum spotkania z przestrzenią umieszcza doświadczenie indywidualne. Spostrzeżenia najpierw zbierane są poprzez zmysły, a potem stają się początkiem refleksji egzystencjalnej.

Odmienną postawę wobec pejzażu jako przestrzeni symbolicznej proponuje Sznajderman w książce Pusty las. Doświadczanie miejsca nie tylko jest świadectwem sensorycznego odbioru przestrzeni, spotkania znanego z nieznanym, ale przede wszystkim stanowi podstawę do formowania samoświadomości i tożsamości (Rybicka 2014: 174). Wędrówkom w przestrzeni fizycznej towarzyszą te odbywane przez literaturę, świadectwa mówione i pisane. Definiowanie krajobrazu prywatnego odbywa się z perspektywy przybysza. Autorka wyjechała z Warszawy do Beskidu Niskiego, kupiła dom i razem z Andrzejem Stasiukiem założyła wydawnictwo (Gralewicz-Wolny 2019: 8). Stała się uważną obserwatorką miejsca dotychczas niezwiązanego z historią jej rodziny. O ile Żeromski, jadący na Litwę Miłosz, Iwaszkiewicz odwiedzający Kalnik, przy- 
wołujący „miasto bez imienia” Herbert wracają (realnie i we wspomnieniach) do rodzinnych stron, o tyle narratorka z Pustego lasu musi sięgnąć do pamięci innych, by odczytać znaki ukryte w pejzażu. Warto wspomnieć, że Pusty las należy traktować jako książkę o bogatej warstwie autobiograficznej. Taki sposób pisania nie jest dla autorki nowy, w 2016 wydawnictwo Czarne wydało jej książkę Fałszerze pieprzu. Historia rodzinna. Sznajderman uruchamia śledztwo, którego celem jest nie tyle znalezienie odpowiedzi, co postawienie pytań na temat przeszłości. Można zaryzykować stwierdzenie, że Pusty las rozszerza pojęcie autobiografii - autorka próbuje bowiem zbadać przeszłość miejsca, w którym zamieszkała, i jednocześnie przywołać jak najbardziej wiernie biografie dawnych mieszkańców Czarnego, Wołowca, Olchowca i okolicznych wiosek. Pytania, które jej towarzyszą, i nie zawsze znajdowane odpowiedzi padają wobec refleksji na temat własnego losu. Jak stwierdza Okoński, Sznajderman bierze w opiekę cudze historie i zamieszkuje w obcym pejzażu, aż nieuchronnie staną się jej historią i pejzażem (Okoński 2019: 30). W krótkiej ankiecie przeprowadzonej wśród nominowanych do Nagrody Literackiej Nike 2020 pisarka stwierdziła, że napisała tę książkę dla swoich sąsiadów - „dawnych i obecnych” (Nogaś, Grzymisławski 2020: 97). Sznajderman pisze:

[...] nie mogę się nadziwić, co tu właściwie robię, w tej „ruskiej okolicy”, na wysiedlonej Łemkowszczyźnie, wśród zrujnowanych cerkwi i zdziczałych sadów, cmentarzy z pierwszej wojny światowej i czarnych kiwonów - jedynych śladów po zapomnianym naftowym imperium wśród cudzych chałup i cudzych rzeczy, w cudzym pejzażu podpierającym niskie niebo (Sznajderman 2019: 23).

Punktem wyjścia do badań w archiwach, do wsłuchiwania się w opowieści tych, którzy zostali lub powrócili do rodzinnych wsi, są znaki zapisane w krajobrazie. Jego poszczególne elementy takie jak drogi, ścieżki, pola, sady są, podobnie jak przedmioty, obdarzone wartościami emocjonalnymi (Bodei 2019: 38). Narratorka układa je w systemy relacji i odkrywa kolejne warstwy przeszłości. Autorka stwierdza: „[...] staram się przywrócić krajobrazowi przeszłość, a jego twórcom - imiona i nazwiska, choćby niektóre, choćby kilka, tyle, ile zdołam” (Sznajderman 2019: 32). W Pustym lesie rozbrzmiewają imiona dawnych mieszkańców, autorka zasiedla przestrzeń: przywołuje nazwiska, adresy, przedmioty. Wskazuje na to, że snucie opowieści jest formą pamięci. Pusty las łączy w sobie reporterskość z intymnością biografii, badawczą skrupulatność z baśniowością i chęcią uchwycenia fenomenu miejsca w kategoriach swoistego toposu. Baśniowość, sygnalizowana przez odrealnianie czasu oraz gawędową narrację, 
uruchamia mechanizm „wiecznego istnienia” (Gralewicz-Wolny 2019: 8). Słowu zostaje powierzona rola zaklęcia, które przywołuje nieobecnych - tych, którzy po sobie „zostawili krajobraz” (Sznajderman 2019: 33). Okoński pisze, że ta „książka przypomina odprawianie dziadów po tych, którzy - no właśnie, nie wiadomo, odeszli czy nie odeszli [...]” (Okoński 2019: 30).

Narratorka to uważna obserwatorka i interpretatorka krajobrazu, która stara się dotrzeć do jak najgłębszych warstw przeszłości i skazana jest na domysły. W rozciągających się łąkach, w zdziczałych sadach, w zagłębieniach ziemi dostrzega ślady po domach, gospodarstwach, polach uprawnych (Okoński 2019: 31). Opisy opuszczonych miejsc rozrastają się do schodzących w głąb czasu sekwencji. Przykładem jest drobiazgowe wyjaśnienie historii domu w Czarnem: „W Czarnem mieszkałam przez osiem lat w domu bez prądu nad Wisłoką, w domu Jurka, wcześniej Chwałyka, a jeszcze wcześniej, przed Wojną, Wasyla Bajsy" (Sznajderman 2019: 12). Istotna w spotkaniu z krajobrazem jest świadomość przeszłości i chęć jej przywoływania, ale także nieufność wobec wizualnej teraźniejszości. W wywiadzie udzielonym Maciejowi Krupie pisarka mówiła o tym, by „nie zawierzać zielonym skwerom” (Na łące pamięci... 2019: 6). Przywołała słowa Hansa-Jochena Knoblocha, autora przewodnika fotograficznego po NRD, który wskazywał, że krajobraz widziany przez soczewkę aparatu jest tylko pozornie niewinny. Podobnie patrzy na pejzaż Sznajderman. Zastosowana przez nią technika przeplotu różnych planów czasowych (Gralewicz-Wolny 2019: 8) pozwala zobaczyć i zrozumieć teraźniejszość i jednocześnie nie pozwala odejść przeszłości. Warstwa refleksyjna, dotycząca roli pamięci, tożsamości, literatury i świadectwa jest równoważona przez opis przestrzeni doświadczanej w jej konkretności. Stojący w centrum głos narratorki - mieszkanki Beskidu Niskiego - opowiada o świecie wokół poprzez doświadczenie zmysłów. Przestrzeń odbierana jest poprzez zapach i dotyk, a główną formą spotkania z nią jest wędrówka. Konkret, zarówno onomastyczny, jak i reistyczny, buduje warstwę sensualistyczną książki. Ziemia posiada swój ciężar, lepkość, zwierzęta zapach i szorstkość skóry, nadciągający zmierzch temperaturę, rośliny z przydomowych ogrodów nazwy. Konkret pełni także funkcję wyzwalającą opowieść o minionym i przywołuje tych, którzy „odcisnęli swój niewidzialny ślad w krajobrazie” (Sznajderman 2019: 169). Realne doświadczenia bohaterki zostają obdarzone znaczeniem symboliczno-magicznym, a wydarzenia fabularne obecne w planie jednostkowym nabierają wymowy uniwersalnej. Sznajderman otwiera krajobraz na jeszcze jeden czas: magiczny. Poza teraźniejszością potwierdzaną poprzez wzrok, przeszłością zapisaną w archiwach, świadectwach i relacjach istnieje czas, w którym te oba wymiary nakładają się na siebie i niczym wahadło zegara raz przechylają się wstecz, raz wybiegają ku 
przyszłości. Niezwykłość tak wykreowanego czasu wiąże się z pojmowaniem krajobrazu jako palimpsestu: ziemia pokryta jest cienką warstwą skóry, pod którą „bulgoce i kipi historia” (Sznajderman 2019: 66). Bohaterka Pustego lasu zanurza się w tej historii, czyta ze śladów zapisanych w pejzażu i jednocześnie sama dopisuje kolejne znaczenia:

Trudzę się więc, troszczę i uprawiam, krzątam i sprzątam, sadzę i koszę - do pejzażu, w którym przyszło mi żyć, dokładam nowe elementy, z każdym najdrobniejszym gestem zmieniam go na zawsze. Na rozmaite sposoby rzeźbię w materii wsi, do trwań jej niegdysiejszych mieszkańców dolepiam moje trwanie, na ich śladach odciskam swój ślad - tworzę teraźniejszość dla tych, którzy nadejdą po mnie (Sznajderman 2019: 30).

W perspektywie zaproponowanej przez geopoetykę Sznajderman tworzy model miejsca, który jest zbiorem złożonym z osobistych doświadczeń egzystencjalnych, doznań zmysłowych oraz emocji budujących prywatne krajobrazy. Autobiografia łączy się z pamięcią zbiorową, sferą przekonań i wyobrażeń.

W przywołanych przykładach z literatury i diarystyki wspólne jest dla wszystkich autorów prezentowanie krajobrazu jako zbioru miejsc znaczących, który oddziałuje na emocje przebywającego w nim przybysza w sposób multisensoryczny i prowadzi do uchwycenia sensów pozazmysłowych. Spotkanie z krajobrazem pozwala ujawniać znaczące elementy biograficzne bohaterów, a podmiotowi i narratorowi wypowiedzieć refleksję o charakterze egzystencjalnym. W tekstach Żeromskiego i Miłosza doświadczenie krajobrazu związane jest $\mathrm{z}$ biografią i odsłania się w motywie powrotu do rodzinnych stron. Ramę wydarzeń stanowi utrata domu, która choć wynika z odmiennych przyczyn, w obu przypadkach uruchamia potrzebę konfrontacji wspomnień z obecną, realną przestrzenią. W Pustym lesie Sznajderman zanurzenie w pejzażu ma swoje źródło w poszukiwaniu tożsamości i próbie włączenia własnej biografii w ciąg losów dawnych mieszkańców odkrywanych przez narratorkę terenów. Odczucia związane są z gestem solidarności wobec tych, którzy utracili swoje domy i ziemie, co prowadzi do przyjęcia postawy współczucia i przywracania zapomnianego lub przemilczanego. U Żeromskiego wizyta w pamiętanej z dzieciństwa okolicy pogłębia odczucie straty i uświadamia niemożność powrotu. Te doznania potęgują wizerunki przyrody, ukazanej jako ekspansywny żywioł, niesprzyjający, a wręcz utrudniający powroty do minionego. Miejsce zaciera przeszłość, ujawnia przemijanie, jest nieprzychylne. W cyklu Litwa po pięćdziesięciu $d$ wóch latach zetknięcie z prywatnym krajobrazem skutkuje poczuciem odnalezienia utraconego, prowadzi do utożsamienia z pejzażem oraz podkreśla 
zgodę podmiotu na przemijanie. Realna przestrzeń oraz wspomnienia stają się źródłem zachwytu i podlegają procesowi poetyckiej mitologizacji. Miejsce opuszczone w młodości nadal jest miejscem umiłowanym.

W prozie Sznajderman poszerza się perspektywa spojrzenia na krajobraz. Po pierwsze, narratorka interpretuje prywatny krajobraz przez kontekst pejzażu widzianego w makroskali regionu. Jej wędrówki nie tylko dotyczą konkretnej przestrzeni geograficznej, ale też odbywają się niejako w głąb warstw czasu. Indywidualne odczucia splecione są z odkrywaniem przeżyć poprzednich mieszkańców Beskidu Niskiego, łącząc się tym samym z historią zbiorowości i grup etnicznych. Natura jest ukazana jako siła sensualna, przemawiająca przez doznania zmysłowe. Miejsca w zapiskach Sznajderman noszą zaś rany po nieobecnych, opowiadają ich historie, przyjmują rolę świadków i strażników pamięci. Tak ujęta postawa wobec krajobrazu wykracza poza rozpoznania geografii humanistycznej i kieruje się w stronę antropologii kultury.

Warto podkreślić, że literatura może odgrywać ważną rolę w badaniach geografii humanistycznej jako źródło interpretacji. Prozatorskie i poetyckie dokonania odsłaniają bowiem specyfikę indywidualnego kontaktu z krajobrazem, postawy wobec niego i sposoby jego rozumienia. Ujawniają także ramy historyczne, kulturowe, kształtujące odbiór pejzażu. Zapisują doznania przefiltrowane przez sztukę i wzmocnione przez doświadczenia czytelnicze, muzyczne, malarskie. Literackie ujęcia pejzażu wpisują się w koncepcję krajobrazu kulturowego, w której terytorium jest definiowane nie tylko w formie fizycznej, ale również symbolicznej i metaforycznej (Rybicka 2014: 132-133).

Potrzeba odczytywania przeszłości i konfrontowania jej ze współczesnością za pośrednictwem krajobrazu jest doznaniem uniwersalnym, nieodłącznie splecionym z ludzkimi losami i uwikłaniem ich w historię. Dla pisarzy to doświadczenie stanowi znaczący komponent ich drogi literackiej oraz własnej tożsamości. Współczesnym nomadom, czytelnikom i twórcom, dla których często jedynym stałym adresem jest lokalizacja w sieci wirtualnej, potrzebne jest zakorzenienie w ziemi, drzewach, ziołach i chwastach.

\section{| Bibliografia}

Bauchrowicz Magdalena (2012), Przeklęta i błogosławiona: pamięć jako fundament europejskiej tożsamości w refleksji Czesława Miłosza, „Przegląd Humanistyczny", nr 6, s. 29-42. 
Bażan Mykoła (2011), Wspomnienie o Krzemieńcu. List do Jarosława Iwaszkiewicza, przeł. Robert Papieski, w: Jarosław Iwaszkiewicz i Ukraina, red. Robert Papieski, Muzeum im. Anny i Jarosława Iwaszkiewiczów w Stawisku, Podkowa Leśna, s. 166-171.

Berkan Maria (1998), Poetycka Litwa Miłosza, „Acta Universitatis Lodziensis. Folia Litteraria Polonica", nr 1, s. 83-108.

Bodei Remo (2019), O życiu rzeczy, przeł. Alicja Bielak, Wydawnictwo Przypis, Łódź.

Błoński Jan (1998), Miłosz jak świat, Znak, Kraków.

Cieński Marcin (200o), Pejzaże oświeconych. Sposoby przedstawiania krajobrazu $w$ literaturze polskiej w latach 1770-1830, Wydawnictwo Uniwersytetu Wrocławskiego, Wrocław.

Czepczyński Mariusz (2006), Transformations of Central European cultural and landscapes. Between circulations and iconography, "Bulletin of Geography", nr 6, s. 5-15.

Dorocki Sławomir (2008), Kultura $w$ aspekcie badań geograficznych, w: Tożsamość kulturoznawstwa, red. Andrzej Pankowicz, Jarosław Rokicki, Paweł Plichta, Wydawnictwo Uniwersytetu Jagiellońskiego, Kraków, s. 283-287.

Farina Almo, Bogaert Jan, Schipani Ileana (2005), Cognitive landscape and information: new perspectives to investigate the ecological complexity, "Biosystems", nr 79, s. 235-240.

Franaszek Andrzej (2011), Miłosz: biografia, Znak, Kraków.

Frydryczak Beata (2013), Krajobraz. Od estetyki the picturesque do doświadczenia topograficznego, Wydawnictwo Poznańskiego Towarzystwa Przyjaciół Nauk, Poznań.

Gołaszewska Maria (1984), Estetyka rzeczywistości, Instytut Wydawniczy PAX, Warszawa.

Gralewicz-Wolny Iwona (2019), Dolepiam moje trwanie, „Nowe Książki”, nr 5, s. 8-9.

Hutnikiewicz Artur (2000), Żeromski, Wydawnictwo Naukowe Pwn, Warszawa. Ingold Tim (2014), Czasowość krajobrazu, w: Krajobrazy. Antologia tekstów, red. Beata Frydryczak, Dorota Angutek, przeł. Beata Frydryczak, Wydawnictwo Poznańskiego Towarzystwa Przyjaciół Nauk, Poznań, s. 147-148.

Iwaszkiewicz Jarosław (2010a), Dzienniki 1956-1963, t. 3, Czytelnik, Warszawa. Iwaszkiewicz Jarosław (2010b), Książka moich wspomnień, Zysk i S-ka, Poznań. Jędrzejczyk Dobiersław (2001), Wprowadzenie do geografii humanistycznej, Wydział Geografii i Studiów Regionalnych Uniwersytet Warszawski, Warszawa.

Karwińska Anna (2017), Przestrzenie pamięci w miastach o trudnej historii. Konflikty wokół narracji miejskich, „Zeszyty Naukowe. Uniwersytet Ekonomiczny w Krakowie", nr 3, s. 69-86. 
Kowalczyk Andrzej (2008), Krajobraz kulturowy, w: Uwarunkowania i plany rozwoju turystyki, red. Zygmunt Młynarczyk, Alina Zajadacz, Marcin Słowik, Wydawnictwo Naukowe UAM, Poznań, s. 121-138.

Kowalczykowa Alina (1982), Pejzaż romantyczny, Wydawnictwo Literackie, Kraków.

Królikowski Jeremi T., Rykała Ewa (2016), Kontemplacja krajobrazu jako źródło inspiracji twórczości artystycznej, „Prace Komisji Krajobrazu Kulturowego”, nr 34, s. 11-26.

Lyszczyna Jacek (2010), Styl i światopogląd: o oświeceniowej i romantycznej semiotyce pejzażu, w: Alfabet Paszka: Berent, stylistyka (i okolice), Żeromski, red. Jan Jakóbczyk i in., Wydawnictwo Uniwersytetu Śląskiego, Katowice, s. $152-159$.

Madurowicz Mikołaj (2012), Za siedmioma górami... Geografia i literatura świadoma przyjaźń czy intuicyjny romans, w: Geografia Słowackiego, red. Dorota Siwicka, Marta Zielińska, Instytut Badań Literackich PAN, Warszawa, s. $360-382$.

Miłosz Czesław (2011), Wiersze wszystkie, Znak, Warszawa.

Na łace pamięci. Z Moniką Sznajderman rozmawia Maciej Krupa (2019), „Nowe Książki”, nr 5.

Myga-Piątek Urszula (2014), O wzajemnych relacjach przestrzeni i krajobrazu kulturowego. Rozważania wstępne, „Prace Komisji Krajobrazu Kulturowego”, nr 24, s. 27-44.

Niewiadomski Andrzej (2018), Miejsca niewyznaczone, przestrzeń niedookreślona. O problemie definiowania „istoty” terytorium, „Ruch Literacki”, nr 4, s. $391-408$.

Nogaś Michał, Grzymisławski Łukasz (2019), Nike 2020, „Książki. Magazyn do czytania", $\mathrm{nr} 4$.

Okoński Michał (2019), Na łące pamięci, „Tygodnik Powszechny”, nr 15.

Pietrzak Maciej (2008), Krajobraz multisensoryczny i metody jego oceny, w: Uwarunkowania i plany rozwoju turystyki, red. Zygmunt Młynarczyk, Alina Zajadacz, Marcin Słowik, Wydawnictwo Naukowe UAM, Poznań, s. 103-120.

Plit Joanna (2011), Piętno władzy i właścicieli odciśnięte w krajobrazie kulturowym, „Prace Komisji Krajobrazu Kulturowego”, nr 15, s. 78-87.

Pollack Martin (2014), Skażone krajobrazy, przeł. Karolina Niedenthal, Czarne, Wołowiec.

Potaczała Krzysztof (2019), Zostały tylko kamienie. Akcja „Wisła”: wygnanie i powroty, Prószyński i S-ka, Warszawa.

Rambowicz Piotr (2011), Doświadczenie starości w późnej twórczości Czesława Miłosza, „Archiwum Emigracji. Studia - Szkice - Dokumenty”, nr 1-2, s. $174-187$. 
Rembowska Krystyna (2002), Kultura w badaniach geograficznych, w: Kultura jako przedmiot badań geograficznych: studia teoretyczne i regionalne, red. Elżbieta Orłowska, Oddział Wrocławskiego Polskiego Towarzystwa Geograficznego, Wrocław, s. 235-245.

Rodaway Paul (1994), Sensuous geographies: body, sense and place, Taylor\&Francis Group, London.

Rudziewicz Irena (2011), Wspomnienie stron rodzinnych w poezji Czesława Miło$s z a$, ,Volyn’ filolohichna: tekst i kontekst”, nr 2, s. 192-201.

Rybicka Ewa (2014), Geopoetyka. Przestrzeń i miejsce we współczesnych teoriach i praktykach literackich, Universitas, Kraków.

Skrok Zdzisław (2008), Wielkie Rozdroże. Ćwiczenia terenowe z archeologii wyobraźni, „Iskry”, Warszawa.

Sznajderman Monika (2019), Pusty las, Czarne, Wołowiec.

Tarnowska Beata (1996), Geografia poetycka w powojennej twórczości Czesława Miłosza, Wydawnictwo Wyższej Szkoły Pedagogicznej, Olsztyn.

Tobiasz-Lis Paulina (2014), Geografia percepcji. Osiagnięcia, problemy, perspektywy, w: Dorobek polskiej geografii po konferencji w Rydzynie. Ocena krytyczna, red. Wiesław Maik, Krystyna Rembowska, Andrzej Suliborski, Wydawnictwo Uniwersytetu Łódzkiego, Łódź, s. 127-141.

To jest we mnie. Rozmowa $z$ Czesławem Miłoszem - przeprowadziła Katarzyna Janowska (2000), „Polityka”, nr 41.

Traba Robert (2009), Przeszłość w teraźniejszości: polskie spory o historię na początku XXI wieku, Wydawnictwo Poznańskie, Poznań.

Trzeszczyńska Patrycja (2013), Łemkowszczyzna zapamiętana. Opowieści o przeszłości i przestrzeni, Wydawnictwo Uniwersytetu Jagiellońskiego, Kraków.

Tuan, Yi-Fu (1987), Przestrzeń i miejsce, przeł. Agnieszka Morawińska, Państwowy Instytut Wydawniczy, Warszawa.

Vincenz Stanisław (1980), Z perspektywy podróży, Znak, Kraków.

Wieczorkiewicz Anna (2008), Apetyt turysty. O doświadczeniu świata w podróży, Universitas, Kraków.

Zajas Krzysztof (2007), Epifanie botaniczne Czesława Miłosza, „Wielogłos: pismo Wydziału Polonistyki uj. 1897-1962", nr 1, s. 110-118.

Zawadzka Danuta (2014), Krajobraz, mapa, pejza $\dot{z}$ - powinowactwa romantyczne, w: Geografia i metafora, red. Elżbieta Konończuk i in., Wydawnictwo Uniwersytetu w Białymstoku, Białystok.

Zieniewicz Andrzej (1987), Rozmowa, biografia, szczegót, „Zeszyty Naukowe Uniwersytetu Jagiellońskiego. Prace Historyczno-Literackie”, nr 61, s. 19-30.

Żeromski Stefan (1954), Dzienniki, t. 2, Czytelnik Warszawa.

Żeromski Stefan (1982), Ludzie bezdomni, Wydawnictwo Lubelskie, Lublin. 


\section{| Abstrakt \\ Mągorzata Peroń \\ Nie ma domu. Krajobraz kulturowy w literaturze (wybrane przykłady)}

Artykuł obejmuje tematykę związaną z geografią kulturową i jej związkami z literaturą. W spotkaniu tych dziedzin powstają zagadnienia przynależne do geopoetyki, przestrzeni pamięci i narracji o tożsamości. Tekst prezentuje literackie transpozycje przeżyć osób doświadczających wspomnień związanych z utratą domu. Są one skonfrontowane z rodzinnym krajobrazem. Utwory literackie i osobiste wspomnienia ukazują koncepcję symbolicznego rozumienia krajobrazu (Żeromski, Iwaszkiewicz, Miłosz).

Monika Sznajderman w książce Pusty las odtwarza pamięć miejsc, z których ludzie zostali wysiedleni. Głos pisarza staje się głosem strażnika pamięci o ich krzywdzie. Odczytywanie ukrytych w krajobrazie znaczeń prowadzi do odkrywania biografii osobistych i historii narodów i mniejszości etnicznych

Słowa kluczowe: krajobraz kulturowy; geopoetyka; antropologia kulturowa

\section{| Abstract}

Matgorzata Peroń

There is no Home. Cultural Landscape in Literature (selected examples)

The article covers issues related to cultural geography and its relations with literature. In the meeting of these domains, issues related to geopoetics, memory space and narratives about identity arise. The text presents literary transpositions of experiences of people who have memories connected with losing their home. They are confronted with the family landscape. Literary works and personal memories show the concept of a symbolic understanding of landscape (Żeromski, Iwaszkiewicz, Miłosz).

Monika Sznajderman in her book Empty Forest recreates the memory of places from which people were displaced. The writer's voice becomes the voice of the guardian of the memory of their harm. Reading the meanings hidden in the landscape leads to discovering personal biographies and the history of nations and ethnic minorities.

Keywords: cultural landscape; cultural anthropology; geopoetics 


\section{| Nota o autorze}

Małgorzata Peroń - dr, ukończyła filologię polską i historię sztuki, pracuje w Instytucie Literaturoznawstwa Katolickiego Uniwersytetu Lubelskiego. Uzyskała tytuł doktora literaturoznawstwa na podstawie rozprawy „Plastyczna mapa świata. Poezja ks. Janusza Stanisława Pasierba wobec sztuki wizualnych”. Do głównych obszarów badawczych należą: twórczość Zbigniewa Herberta, Janusza S. Pasierba, literatura i krytyka polska po roku 1989, wizualność w kulturze.

E-mail: malgorzata.peron@kul.pl

ORCID: 0000-0002-3244-7443 